\title{
Surgical Treatment of Synchronous Multiple Primary Lung Cancer: Report of Two Cases
}

\author{
Recep Demirhan, ${ }^{1}$ Kadir Burak Özer, ${ }^{1}$ Ekin Ezgi Cesur, ${ }^{1}$ Attila Özdemir, \\ Dilek Ece, ${ }^{2}$ Fatma Tuğba Özlü ${ }^{1}$
}

\author{
'Department of Thoracic Surgery, \\ University of Health Sciences, \\ Kartal Dr. Lütfi Kırdar Training and \\ Research Hospital, İstanbul, Turkey \\ ${ }^{2}$ Department of Pathology, \\ University of Health Sciences, \\ Kartal Dr. Lütfi Kırdar Training and \\ Research Hospital, İstanbul, Turkey \\ Submitted: 21.12.2017 \\ Accepted: 25.12.2017 \\ Correspondence: Recep Demirhan, \\ Kartal Dr. Lütfi Kırdar Eğitim ve \\ Araştırma Hastanesi Göğüs \\ Cerrahisi Kliniği, İstanbul, Turkey \\ E-mail: recepdemirhan@hotmail.com
}

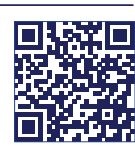

Keywords: synchronous tumor, multiple lung cancer, surgical treatment, metachronous tumor

\begin{abstract}
The presence of more than I distinct lung cancer in the same patient, or multiple primary lung cancer (MPLC) is a rarely seen condition. Multiple lung cancers are classified as synchronous when more than I type of lung cancer is detected at the same time, and as metachronous tumors if the second tumor is detected some months after the first lesion. Synchronous tumors are more rare and the treatment and prognosis differs from that observed in metastatic lung cancers. In recent years, thanks to the development of radiological modalities, such as multislice computed tomography and positron emission tomographycomputed tomography, as well as invasive diagnostic methods, such as endobronchial ultrasound, transthoracic needle aspiration biopsy, and transbronchial needle aspiration biopsy, the detection rate of synchronous tumors has increased.
\end{abstract}

\section{INTRODUCTION}

The presence of more than I distinct lung cancer in the same patient is rare. Multiple primary lung cancer (MPLC) was first described in a 1924 autopsy examination by Beyreuther. ${ }^{[l]}$ Multiple lung cancers may be synchronous or metachronous tumors. When more than I type of lung cancer is detected at the same time, it is called a synchronous tumor, while if the second tumor is detected later, it is called a metachronous tumor. Synchronous tumors are more rare than metachronous tumors, and the treatment and prognosis differs from that of metastatic lung cancers. This study is a description of the characteristics seen in 2 cases of MPLC and the diagnostic and therapeutic procedures followed, discussed in the context of the literature.

\section{CASE REPORT}

Case I- Upon detection of opacity with irregular contours localized in the upper lobe of the right lung on a posteroanterior (PA) chest X-ray of a 53-year-old male patient, another center referred the patient to our facility. The overall status of the patient was good and his vital findings were stable. He had a smoking history of 20 packyears, and reported back pain and coughing persisting for I month. His family history was unremarkable. A physical examination revealed a body temperature of $36.8^{\circ} \mathrm{C}$, blood pressure of $140 / 85 \mathrm{mmHg}$, pulse rate of $100 /$ minute, and a respiratory rate of $20 /$ minute. Examination findings of the chest and other bodily systems were within normal limits. Hemogram, urinalysis, and other biochemical laboratory findings were within the normal ranges. The 

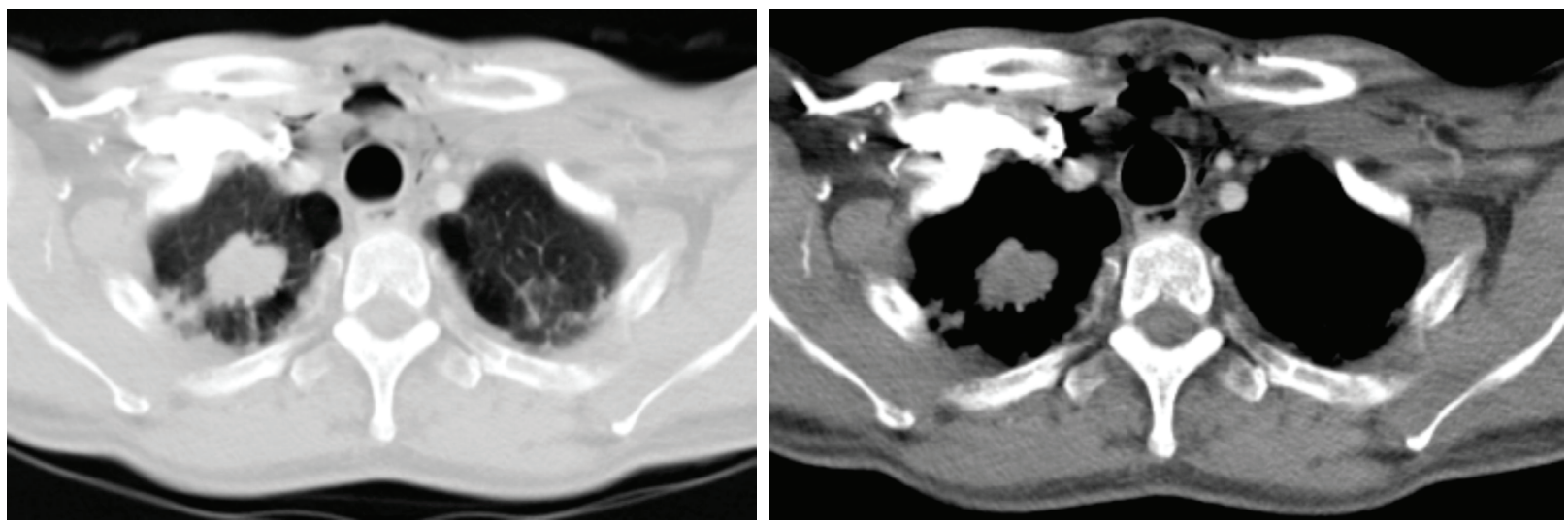

Figure 1. Thoracic computed tomography images of the apical areas of the right and left lungs.

erythrocyte sedimentation rate (ESR) was measured at 48 $\mathrm{mm} /$ hour.

A thoracic computed tomography (CT) image demonstrated a solid lesion, $2.5 \times 2.5 \times 1.5 \mathrm{~cm}$ in size, with irregular contours and spicular projections localized in the apical area of the right lung. A second lesion in the apical area of the left lung measuring approximately $1 \times 0.5 \times 0.5 \mathrm{~cm}$ was also reported.

The right and left bronchial systems were assessed as normal in a fiberoptic bronchoscopic evaluation. Transthoracic fine-needle biopsy (TTFNAB) was performed for the mass lesion in the right lung, and as the histopathology result was consistent with adenocarcinoma, a staging positron emission tomography-computed tomography (PET-CT) scan was performed. PET-CT did not indicate any pathological involvement other than lesions in the right (maximum standardized uptake value [SUVmax]: 7.9) and left (SUVmax 5.8) lungs. The histopathology result of the specimen obtained from the lesion in the left lung was a malignant lesion, so surgical intervention was planned. The patient underwent staging video mediastinoscopy under general anesthesia. Malignancy was not detected in the mediastinal lymph nodes. A pulmonary function test yielded a forced expiratory volume in I second (FEVI) of 93\% (3.47 L). A right thoracotomy was performed, followed by a right upper lobectomy. The patient did not develop postoperative complications and was discharged on the fifth postoperative day. Four weeks later he was readmitted, and a left thoracotomy and left upper lobectomy were performed for the lesion in the left upper lobe. A postoperative pathology report described the right upper lobe tumor as well-differentiated acinar adenocarcinoma, while the histopathology of the left upper lobe tumor was reported as poorly differentiated, solid-type adenocarcinoma. This lesion was considered a synchronous tumor. The patient was evaluated by the tumor council of the hospital, and no additional medical treatment was planned. The patient has been disease-free and has had no problem for 3 years of follow-up.

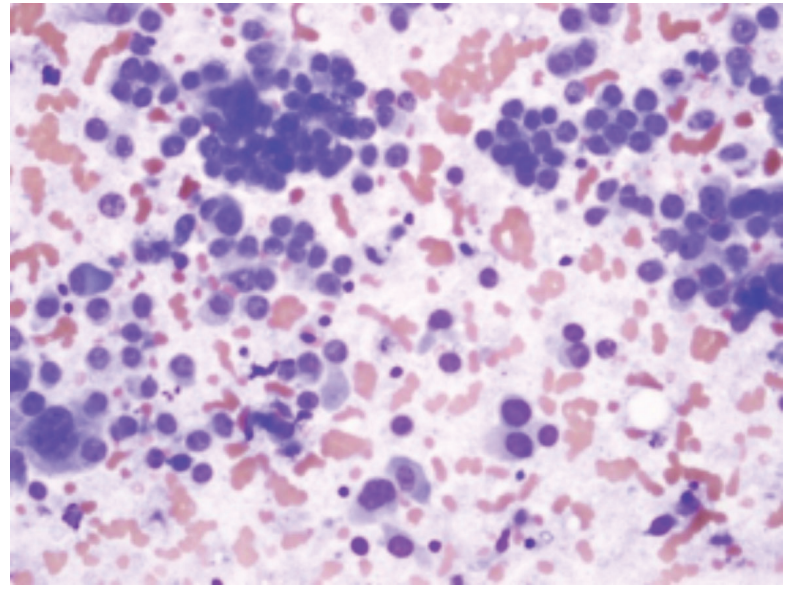

Figure 2. Acinar type adenocarcinoma (well differentiated).

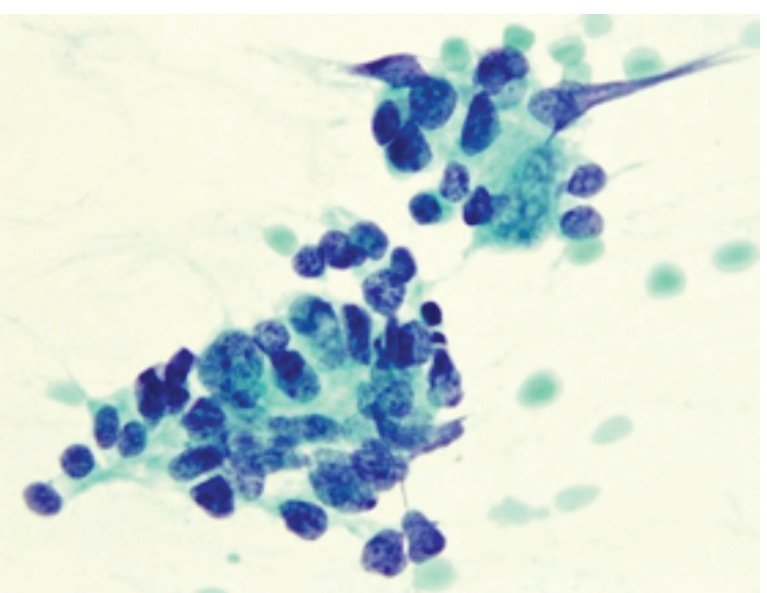

Figure 3. Solid-type adenocarcinoma (poorly differentiated).

Case 2- A PA chest radiogram of a 53-year-old male patient who was referred to the polyclinic with complaints of shortness of breath and right flank pain revealed opacity with irregular contours and a nearby round lesion with regular contours in the lower lobe of the right lung. The patient reported right flank pain persisting for I month and had a smoking history of 40 pack-years. He had undergone a partial laryngectomy and adjuvant neck radio- 

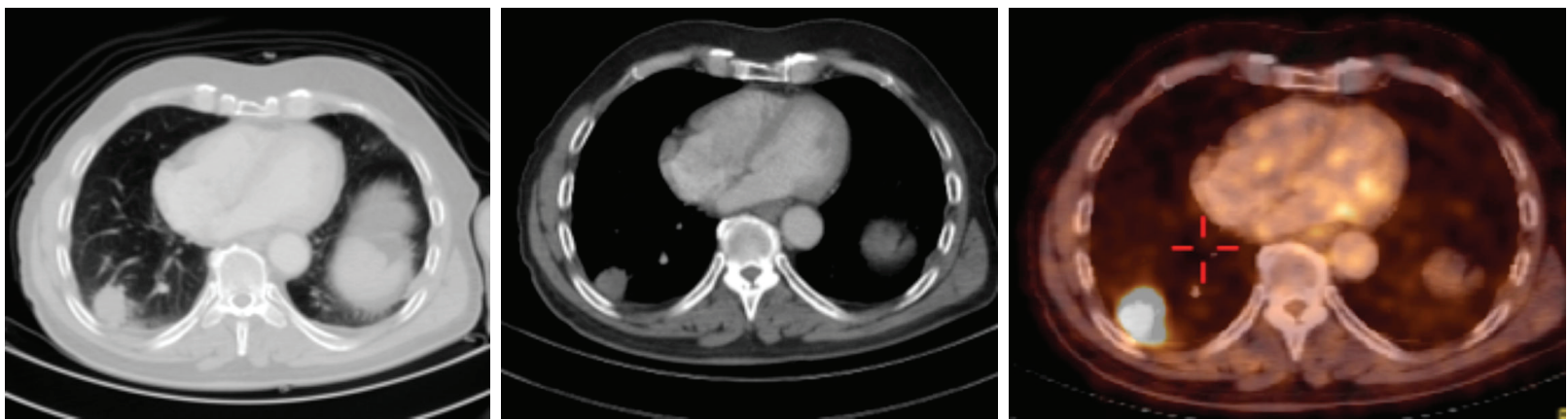

Figure 4. Positron emission tomography-computed tomography images of a mass lesion in the lower lobe of the right lung.
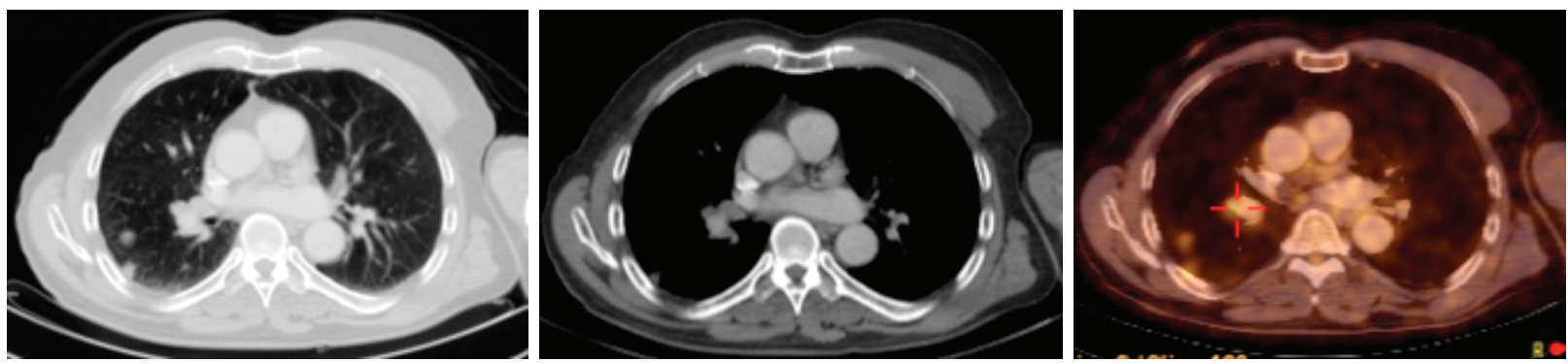

Figure 5. Positron emission tomography-computed tomography images of a nodule in the vicinity of the mass lesion in the lower lobe of the right lung.

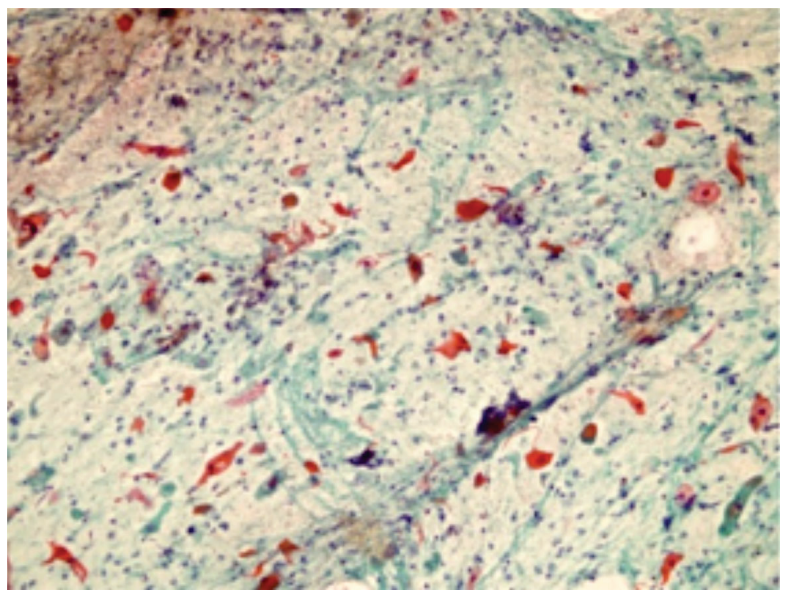

Figure 6. Squamous cell carcinoma.

therapy 10 years previously with the indication of laryngeal carcinoma. His family history was unremarkable. On physical examination, his body temperature was $36.5^{\circ} \mathrm{C}$, blood pressure was $130 / 65 \mathrm{mmHg}$, pulse rate was $96 /$ minute, and his respiratory rate was $18 /$ minute. Pulmonary and other system examinations were unremarkable. Hemogram and biochemical analysis results were normal. The ESR was measured as $23 \mathrm{~mm} /$ hour.

Thoracic CT revealed a mass lesion with spicular projections measuring $25 \times 28 \mathrm{~mm}$ localized in the subpleural area in the laterobasal segment of the lower lobe of the right lung, and a neighboring nodule $12 \mathrm{~mm}$ in size.

Fiberoptic bronchoscopy revealed normal right and left bronchial systems. TTFNAB was performed for the mass

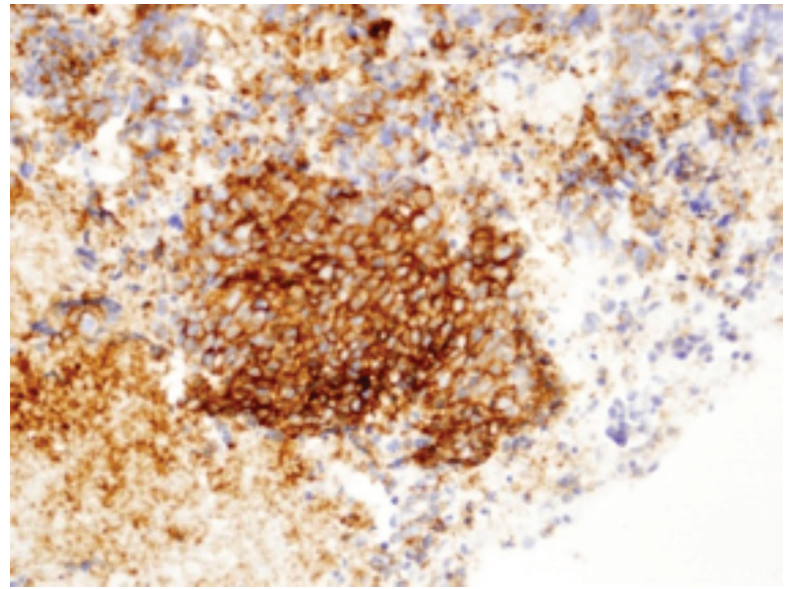

Figure 7. Small-cell lung carcinoma.

lesion in the laterobasal segment of the right lung. Histopathology of the specimen was consistent with squamous cell carcinoma, so the patient underwent staging PET-CT. The PET-CT report revealed no pathological involvement other than the mass lesion in the lower lobe of the lung (SUVmax: 33.9) and the nearby 12-mm parenchymal nodule (SUVmax: 5.0). His FEVI was 8I\% (2.32 L). A staging video mediastinoscopy was performed under general anesthesia. Frozen section examination of the mediastinal lymph nodes did not reveal any malignancy. A right thoracotomy was used to perform a right lower lobectomy and to dissect the mediastinal lymph node.

Postoperative pathology of the $3.1-\mathrm{cm}$ mass was reported as squamous cell carcinoma and the $1.2-\mathrm{cm}$ lesion was classified as small cell carcinoma. A diagnosis of synchro- 
nous lung tumors was made. The case was discussed in a multidisciplinary council, and the patient was referred to the oncology clinic due to the presence of small cell carcinoma.

\section{DISCUSSION}

These 2 cases were diagnosed as synchronous MPLC. Beyreuther first described MPLC based on an autopsy performed in 1924. ${ }^{[1]}$ In 1975, Martini and Melamed ${ }^{[2]}$ defined the discriminative criteria for a synchronous tumor and metastasis (Table I).

In various sources, the incidence rate of MPLC has been reported to range between $0.8 \%$ and $14.5 \%$. A higher rate may be a result of the development of imaging techniques, earlier diagnosis of lung cancer, the modernization of surgery, new treatment modalities, and the increased survival time of lung cancer patients. ${ }^{[2-4]}$ Synchronous tumors are 2 different types of lung tumors diagnosed at the same time, while the diagnosis of metachronous tumors requires 2 primary tumors detected after an interval of at least 12 months. ${ }^{[5,6]}$ Many diagnostic criteria for MPLC have been defined. Antakli et al. ${ }^{[7]}$ reported that to make a diagnosis of MPLC, the tumors should have different histological types or, for tumors of the same histological type, at least 2 of the following criteria should be present: the tumors are localized in anatomically different sites; there is an associated, premalignant lesion; there is no evidence of distant metastasis or mediastinal invasion; or different DNA ploidy are found.

In $60 \%$ of the patients with synchronous MPLC the histopathological diagnosis is squamous cell carcinoma, and some $60 \%$ of MPLC tumors are of the same histopathological type. ${ }^{[8]}$ The co-existence of small cell and non-small cell cancers is rare. ${ }^{[9]}$ One of our cases had a different subtype of adenocarcinoma as the second cancer, while in the other case, the presence of small cell and non-small cell carcinomas was noteworthy. Many different treatment modalities have been used in the management of cases with MPLC. Surgical treatment is recommended for patients with tumors meeting resectability criteria. ${ }^{[10]}$ In eligible patients with ipsilateral synchronous tumors, anatomical resection of any type, including pneumonectomy, can be applied. However if the tumors are bilateral, then a consecutive surgical treatment protocol is applied at an interval of 4 to 6 weeks, starting with the resection of the higher-stage tumor. $^{\left[{ }^{11}\right]}$ In I of our cases, the tumors were localized in the same lobe, so a lobectomy was performed. In the other case, consecutive upper lobectomies were performed bilaterally. Dijkman et al.. ${ }^{[2]}$ suggested that SUV results measured with fluorodeoxyglucose (FDG) PET might be helpful in discriminating between synchronous MPLC and metastatic lesions. In that retrospective study, mean SUV values obtained in cases with synchronous primary tumors
Table I. Martini and Melamed diagnostic criteria for multiple primary lung cancers

Metachronous tumors

I. The histological type is different

II. The histological type is the same, and

A. The second tumor appears at least 2 years after the first,

B. The origin of the second cancer is carcinoma in situ,

C. The subsequent cancer is in a different lobe or lung, but

I. The common lymph nodes have no evidence of carcinoma, and

2. There is a lack of extrapulmonary metastasis at the time of diagnosis

Synchronous tumors

I. The tumors are localized in anatomically different sites

II. The histological type is

A. Different

B. The same, but localized in a different segment, lobe or lung, and

I. The origin of the second cancer is carcinoma in situ,

2. The common lymph nodes have no evidence of carcinoma, and

3. There is a lack of extrapulmonary metastasis at the time of diagnosis

Table 2. Modification of criteria made by Antakli et al. in 1995

A Different histological type

B The same histological structure and presence of $\geq 2$ of the following:

I. The tumors are in anatomically different locations,

2. There is an association with a premalignant lesion,

3. There is an absence of any systemic metastasis,

4. There is an absence of any mediastinal spread, or

5. There are different DNA ploidy.

were higher than those of the metastatic group $(8.58 \pm 5.24$ vs. $4.00 \pm 4.22$ ). FDG-PET staging was performed for both of our cases. The SUV value of the patient with small cell carcinoma component was higher (SUVmax: 33.4) than that observed in Dijkman's study; however, the SUV value of our other case was similar (SUVmax: 7.4).

Differentiation between synchronous tumors and metastatic lung cancer is of great importance. Different treat- 
ment plans will have diverse survival outcomes. It has been demonstrated that the long-term survival of cases with MPLC who had undergone surgical tumor resection was more prolonged when compared with metastatic stage IV patients. Therefore, since a surgical approach for patients with resectable tumors offers longer survival, it is an important treatment alternative. ${ }^{[14]}$ We think that curative surgical resection contributed to the survival of our 2 patients.

\section{Conclusion}

Although synchronous primary lung cancers are rarely seen, they have become more detectable in recent years with the growing use and number of radiological and invasive diagnostic methods. We believe that survival outcomes with surgical treatment will improve with earlier diagnosis and surgical treatment.

\section{Informed Consent}

Approval was obtained from the patients.

Peer-review

Internally peer-reviewed.

Authorship Contributions

Concept: R.D.; Design: K.B.Ö.; Data collection \&/or processing: A.Ö.; Analysis and/or interpretation: K.B.Ö.; Literature search: F.T.Ö.; Writing: K.B.Ö.; Critical review: E.E.C.

Conflict of Interest

None declared.

\section{REFERENCES}

1. Aziz TM, Saad RA, Glasser J, Jilaihawi AN, Prakash D. The management of second primary lung cancers. A single centre experience in 15 years. Eur J Cardiothorac Surg 2002;21:527-33. [CrossRef]

2. Martini N, Melamed MR. Multiple primary cancers. J Thorac Cardiovasc Surg 1975;1:948-56.
3. Toker A, Kalaycı G. İkinci primer akciğer kanserlerinde cerrahi tedavi. In: Yüksel M, Kalaycı G, editors. Göğüs Cerrahisi. İstanbul: Bilmedya; 2001. p. 347-52.

4. Adebonojo SA, Moritz DM, Danby CA. The results of modern surgical therapy for multiple primary lung cancers. Chest 1997;112:693701. [CrossRef]

5. Carey FA, Donnelly SC, Walker WS, Cameron EW, Lamb D. Synchronous primary lung cancers: prevalence in surgical material and clinical implications. Thorax 1993;48:344-6. [CrossRef]

6. Coffman B, Crum E, Forman WB. Two primary carcinomas of the lung: adenocarcinoma and a metachronous squamous cell carcinoma. A case report and review of the literature. Cancer 1983;51:124-6.

7. Antakli T, Schaefer RF, Rutherford JE, Read RC. Second primary lung cancer. Ann Thorac Surg 1995;59:863-6. [CrossRef]

8. Detterbeck FC, Jones DR, Kernstine KH, Naunheim KS; American College of Physicians. Lung cancer. Special treatment issues. Chest 2003;123:244S-58S. [CrossRef]

9. Hiraki A, Ueoka H, Yoshino T, Chikamori K, Onishi K, Kiura K, et al. Synchronous primary lung cancer presenting with small cell carcinoma and non-small cell carcinoma: diagnosis and treatment. Oncol Rep 1999;6:75-80. [CrossRef]

10. van Rens MT, Zanen P, Brutel de La Rivière A, Elbers HR, van Swieten HA, van Den Bosch JM. Survival in synchronous vs, single lung cancer: upstaging better reflects prognosis. Chest 2000;118:952-8.

11. Adebonojo SA, Moritz DM, Danby CA. The results of modern surgical therapy for multiple primary lung cancers. Chest 1997;112:693701. [CrossRef]

12. Dijkman BG, Schuurbiers OC, Vriens D, Looijen-Salamon M, Bussink J, Timmer-Bonte JN, et al. The role of (18)F-FDG PET in the differentiation between lung metastases and synchronous second primary lung tumours. Eur J Nucl Med Mol Imaging 2010;37:2037-47.

13. Uçgun İ, Akçayır Şahin İ, Metintaş M, Alataş F, Erginel S, Dündar E. Senkron Primer Akciğer Kanserleri: dört olgu nedeni ile. Toraks ve Tuberkuloz Dergisi 2004;52:262-7

14. Tülek B, Baba F, İnan E, Kanat F, Süerdem M. Multiple Primary Lung Cancers: Report of Three Cases. Eurasian J Pulmonol 2015;17:54-7.

15. Turhan K, Yoldaş B, Çağırıcı U, Çakan A. Outcomes of Surgical Treatment for Synchronous and Metachronous Lung Cancer. Ege Journal of Medicine 2009;48:85-8.

\section{Senkron Multipl Primer Akciğer Kanserinde Cerrahi Tedavi: İki Olgu Sunumu}

Farklı birden fazla akciğer kanserin aynı hastada bulunması nadir görülen bir durumdur. İlk kez 1924 yılında yapılan bir otopsi sırasında karşılaşılan bu durum 'multipl akciğer kanseri' (MAK) adını almıştır. Multipl akciğer kanseri senkron ve metakron tümör olarak adlandırılır. Aynı anda farklı akciğer kanserinin saptanması senkron, ilk lezyonun saptanmasından belli bir zaman sonrasında ikinci tümör saptanıyorsa metakron tümör olarak adlandırılır. Senkron tümörler, metakron tümörlere göre daha nadir görülüp, tedavi ve prognozu diğer metastatik akciğer kanserlerine göre farklılık gösterir. Son yıllarda çok kesitli bilgisayarlı tomografi (BT), PET-BT gibi radyolojik yöntemler ile EBUS, TTIAB, TBIAB gibi invaziv tanı yöntemlerinin gelişmesi ile birlikte senkron tümörlerin saptanma oranları artmışdır. Bu yazıda, kliniğimizde tanı konulup, ameliyat edilen iki MAK olgusunun özellikleri, tanı ve tedavi süreçleri literatür bilgileri eşliğinde tartışılarak sunuldu.

Anahtar Sözcükler: Cerrahi tedavi; metakron tümör; multipl akciğer kanseri; senkron tümör. 